OPEN ACCESS

Edited by:

Neil H. Shear,

University of Toronto, Canada

Reviewed by:

Takashi Hashimoto,

Graduate School of Medicine, Osaka

University, Japan

Hiroaki Iwata,

Hokkaido University, Japan

*Correspondence:

Khalaf Kridin

dr_kridin@hotmail.com

Specialty section:

This article was submitted to

Dermatology,

a section of the journal

Frontiers in Medicine

Received: 30 May 2018

Accepted: 17 July 2018

Published: 20 August 2018

Citation:

Kridin K and Ludwig RJ (2018) The

Growing Incidence of Bullous

Pemphigoid: Overview and Potential

Explanations. Front. Med. 5:220.

doi: 10.3389/fmed.2018.00220

\section{The Growing Incidence of Bullous Pemphigoid: Overview and Potential Explanations}

\author{
Khalaf Kridin ${ }^{*}$ and Ralf J. Ludwig ${ }^{2}$ \\ ${ }^{1}$ Department of Dermatology, Rambam Health Care Campus, Haifa, Israel, ${ }^{2}$ Lübeck Institute of Experimental Dermatology, \\ University of Lübeck, Lübeck, Germany
}

Bullous pemphigoid (BP) is the most common type of subepidermal autoimmune bullous diseases. BP characteristically affects the elderly and is seen mainly in patients older than 70 years. While the annual incidence of BP has been estimated to be between 2.4 and 23 cases per million in the general population, it rises exponentially to 190-312 cases per million in individuals older than 80 years. In addition, a growing body of evidence reports a remarkable trend of increased incidence of BP, showing a 1.9- to 4.3-fold rise over the past two decades. This demonstrable increase warrants a higher awareness of the increased risk to develop BP. This review summarizes the current understanding of the epidemiological features of BP and sheds light on the putative explanations for its growing incidence.

Keywords: bullous pemphigoid, epidemiology, explanation, review of literature, incidence, DPP-4 inhibitors, longevity

\section{THE GENERAL EPIDEMIOLOGY OF BP}

Bullous pemphigoid (BP) is the most common type of subepidermal autoimmune bullous diseases (1). The disease develops characteristically in the elderly, particularly in patients older than 70 years (2-5). The annual incidence of BP has been estimated to range between 2.4 and 21.7 new cases per million population in different populations worldwide $(2,3,6-11)$. An even higher annual incidence of 42.8 cases per million population was reported in the United Kingdom (UK), although this report may be interpreted with caution as it is based on a computerized longitudinal general practice database (12). Also based on health insurance data, the prevalence of BP has recently been estimated at 259 per million population in Germany, i.e., $\sim 21,000$ patients with BP lived in Germany as for 2014 (13). Despite this increase, BP is still considered as an orphan disease, i.e., $<5$ in 100,000 persons are affected by the disease (14).

$\mathrm{BP}$ is traditionally considered as a disease of the elderly population. The mean age of presentation ranges between 66 and 83 years in different cohorts across the globe $(9,15)$. The incidence rises exponentially with age, culminating at 190 to 312 cases per million per year in individuals older than 80 years of age $(3,11,12,16)$. Conversely, BP is rarely encountered in individuals younger than 50 years, with the reported incidence rates usually lower than 0.5 cases per million population in this age category $(3,8,12,17)$. This is atypical for an autoimmune disease, caused by an autoantibody response toward the hemidesmosomal proteins BP180 and BP230 (18-22), as autoimmune diseases usually arise during young adulthood (23-25). 
An evident female preponderance was noted in the majority of studies, with a female-to-male ratio ranging between 1.04 and $5.1(2,4,6,7,9,12,15,26-28)$. Several studies found that the incidence rate seems to be higher in women until the age of 75 , but thereafter the incidence is higher in men $(3,9,17)$.

\section{OVERVIEW OF THE INCREASING TREND IN DIFFERENT REGIONS IN THE LAST TWO DECADES}

A growing incidence ranging from 1.9- to 4.3-fold in the past two decades has been reported in recent data from the UK, France, Germany, and Israel (Table 1) (2, 9, 12, 17, 28).

In a retrospective cohort study, the annual incidence of $\mathrm{BP}$ was estimated at 21.7 cases per million population throughout the years 2000-2005 in three French regions: Haute-Normandie, Limousin, and Champagne-Ardennes (9). This figure represents more than 3 -fold increase relative to the annual incidence previously estimated in three adjacent French regions between the years 1986-1992: Limousin, Touraine, and Picardie, with very similar demographic characteristics (6.7 cases per million population) (2). This rise corresponds to an average increase of approximately one case per million per calendar year (9).

In accordance to the French study, very similar incidence rates had been concurrently calculated in two German regions during a similar period, namely Lower Franconia (6.1 cases per million population) and Northwestern Bavaria (6.6 cases per million population), between the years 1989-1997 and 19891994 , respectively $(28,29)$. Bertram et al. (8) reported a 2.2 -fold increase in annual incidence rate in Lower Franconia in 20012002 (13.4 cases per million population) as compared to the previous study.

A consistent rise of the annual incidence rates of BP has been reported in the UK during the last two decades; from a nadir of 10.0 cases per million population in 1985 (30), to 14.0 cases per million population during 1991-2001 (11), and up to 42.8 cases per million population during the 2001-2004 (12). However, the last study may be biased by overestimation as was previously discussed (12).

A recent population-based study investigating the epidemiology of BP in Northern Israel revealed a 1.9-fold increasing annual incidence: from 7.6 to 14.3 cases per million population in the calendar periods 2000-2005 and 2011-2015, respectively. This rise applied to both of the major ethnic populations residing in the region: Jews and Arabs (17).

\section{PUTATIVE EXPLANATIONS FOR THIS SURGE}

\section{Increasing Life Expectancy of the Populations}

Global mean life expectancy increased substantially by 5.5 years between 2000 and 2016, the most rapid increase observed since the 1960s (31). Over the past 15 years, a 2.9 year increase in life expectancy has occurred in the European Union countries, rising from 77.7 to 80.6 years; the rise was 2.4 years for women and 3.4 years for men (32). This rapid rise was attributed to several putative factors including the improved lifestyles, rising living standards, better education, and advanced healthcare and medicine (32). Given the increasing incidence rate of BP with age, the higher longevity account for part of the increased overall incidence of BP throughout the years.

In countries where rising incidence of $\mathrm{BP}$ was reported, a parallel rise in life expectancy was observed. In France and the UK between 1980 and 2000, life expectancy rose from 74.1 to 79.2 years and from 73.7 to 78.0 years, respectively $(32,33)$. In 2015 , life expectancies in these two countries further increased to 82.4 and 81.0 years, respectively (32). In Germany, the life expectancy increased consistently, rising from 73.1 in 1980 to 78.3 in 2000 and reaching 80.7 in 2015 (32). When examining fluctuations in the life expectancy throughout the relevant period in Israel, a 3 years increase was identified; from 79.0 in 2000 to 82.1 in 2015 (33). Considering the aging trend of the European population, even more individuals are expected to develop BP in the coming decades.

\section{Increasing Incidence of Disabling Neurological Conditions}

A large body of evidence gathered within the past decade suggests a high association between neurological disorders and BP. The prevalence of neurological comorbidities among patients with BP ranges between 28 and 56\% (34-37). In addition, neurological conditions were found to be an independent risk factor for the subsequent development of BP as revealed by several welldesigned observational studies $(16,38-40)$. The presence of coexisting neurological disease at the onset of $\mathrm{BP}$ was found to be a bad prognostic factor $(39,41-43)$.

The burden of neurological disease has grown remarkably within the past few decades (44). The increasing number of individuals affected by these diseases has mainly been associated with the aging of the population and population growth (44). There was a large rise in the absolute numbers of prevalent cases of Alzheimer's disease and other dementias $(44,45)$. In addition, an increasing incidence of stroke (46), epilepsy (47), and intracranial malignancies in elderly people (48), as well as growing prevalence of multiple sclerosis $(49,50)$ have been reported in different regions. The increasing burden of these neurological conditions, found to be an established risk factor for $\mathrm{BP}$, may account for part of the rising incidence of BP.

One of the widely accepted explanations for this association is the cross-reactivity between the neuronal and epithelial isoforms of BP Antigen-1 (BP230), which are both encoded by dystonin gene (DST) (51-55). Mice with mutations in this gene developed severe dystonia and sensory nerve degeneration, further supporting this concept (56). Additionally, a large amount of evidence suggests that BP180 may also be expressed in certain components of the central nervous system $(54,55)$.

\section{Increasing Use of Certain Culprit Drugs Dipeptidyl-Peptidase IV Inhibitors}

Growing evidence suggests that dipeptidyl-peptidase IV inhibitors (DPP4i), new anti-hyperglycemic oral agents used to treat type 2 diabetes mellitus, may be implicated in the development of BP $(57,58)$. Sitagliptin was the first DPP4i agent to gain US Food and Drug Administration approval 
TABLE 1 | Increase in bullous pemphigoid incidence across different populations.

\begin{tabular}{|c|c|c|c|c|c|}
\hline Country & First incidence rate & Second incidence rate & Third incidence rate & Increase* & References \\
\hline France & 6.7 (1986-1992) & 21.7 (2000-2005) & & 3.3-fold within 14 years & $(2,9)$ \\
\hline Germany & $6.1(1989-1997)$ & $6.6(1989-1994)$ & $13.4(2001-2002)$ & 2.2-fold within 8 years & $(8,28,29)$ \\
\hline United Kingdom & $10.0(1985)$ & $14.0(1991-2001)$ & $42.8(2001-2004)$ & 4.3 within 17 years & $(11,12,30)$ \\
\hline Israel & 7.6 (2000-2005) & 12.6 (2006-2010) & 14.3 (2011-2015) & 1.9 increase within 10 years & $(17)$ \\
\hline
\end{tabular}

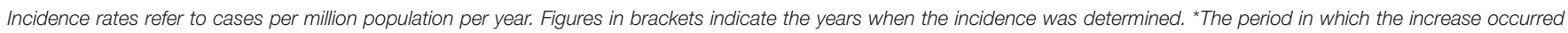
was estimated by calculating the difference between the midpoint of the first and last follow-up periods.

in 2006, followed by vildagliptin (2007), linagliptin (2011), and alogliptin (2013) (57). Since the approval of these agents, their administration has become more widespread as either monotherapy or in conjunction with insulin or other oral antihyperglycemic medications.

The role of DPP4i in triggering BP was grounded mainly on case reports (59-66) and national pharmacovigilance database analyses $(67,68)$ until well-designed controlled observational studies were recently conducted $(57,58)$. Benzaquen et al. (57) reported that DPP4i intake was associated with an increased risk for triggering BP (adjusted OR, 2.64), with vildagliptin being implicated with the highest risk (adjusted OR, 3.57). Varpuluoma et al. (58) found that DPP4i administration was associated with 2.2-fold increased risk for BP (adjusted OR, 2.19), particularly with vildagliptin (adjusted OR, 10.4). The aforementioned studies were underpowered to analyze the association between BP and linagliptin, which is most likely due to the limited number of cases under treatment with this new agent. Kridin and Bergman observed that overall DPP4i intake was associated with a 3-fold increased risk for BP (adjusted OR, 3.16). The adjusted ORs of vildagliptin and linagliptin were 10.67 and 6.65, respectively. Furthermore, a recent Greek retrospective cohort study observed a $38.4 \%$ increase in the prevalence of patients with comorbid type 2 diabetes mellitus in a cohort of 130 patients with $\mathrm{BP}$. This rise was ascribed mainly to the growing prescription of DPP4i (69). Interestingly, DPP4i may in addition increase the risk for another pemphigoid disease, namely mucous membrane pemphigoid (MMP), where exposure to these agents accounted for 24 cases of a total of 313 MMP patients in a recent French cohort study (70).

The clinical and immunological characteristics of DPP4irelated BP were described only in few studies. Izumi et al. (71) reported that seven patients with DPP4i-associated BP tended to present with the non-inflammatory phenotype, characterized by reduced erythema and scant lesional eosinophilic infiltration. Autoantibody reactivity against the midportion of BP-180, but not against the NC-16A immunodominant domain of BP180, was detected in these patients. Recently, Chijiwa et al. (72) reported that the frequency of lesional eosinophilia and mucosal involvement was significantly lower in nine patients with DPP4i-related BP than in 21 patients with non-DPP4i-related BP. Garcia-Diez et al. (73) had recently reported that $4(50 \%)$ out of their 8 patients with DPP4-related BP developed non-inflammatory phenotype, whereas 6 (75\%) were tested positive for anti-NC-16A BP180 autoantibodies in ELISA. In their longitudinal follow-up across 9 years,
Kawaguchi et al. (74) found that 8 patients developed BP while being managed with DPP4i, of whom $6(75 \%)$ had a non-inflammatory phenotype, and 5 of the $6(83.3 \%)$ had been tested negative for anti-NC-16A BP180 autoantibodies in ELISA. The susceptibility to the development of DPP4iassociated BP was found to associate with HLA-DQB1*03:01 allele (75).

The pathomechanism underlying the association between DPP4i and BP has yet to be fully elucidated. It is known that DPP4 is a cell-surface plasminogen receptor that activates plasminogen, which leads to the formation of plasmin (76). The latter is a major serine protease that cleaves BP180 within the immunodominant NC-16A domain and can be detected in lesional skin as well as in blister fluid of patients with BP (77). The inhibition of plasmin by DPP4i may alter the appropriate cleavage of BP180, which may affect its antigenicity and function (71). Additionally, DPP4 inhibition may substantiate the activity of eotaxin and other pro-inflammatory cytokines, leading to cutaneous eosinophil activation and blister formation (78).

\section{Psychotropic Drugs}

The intake of psychotropic medications, particularly phenothiazines with aliphatic side chains, was associated with an increased risk for the development of BP in two well-designed case-control studies $(16,79)$. The prescription of this group of medications has risen over the past few decades, according to studies across different countries $(9,80,81)$. More alarming is the rise of polypharmacy of psychotropic medications within the last decade (80). Again, the mechanisms leading to psychotropic medication-induced BP remain unclear.

\section{Checkpoint-Inhibitors}

The use of checkpoint inhibitors, such as therapeutic monoclonal antibodies targeting cytotoxic T-Lymphocyte Associated Protein 4 (CTLA-4), programmed cell death protein 1 (PD-1), and programmed death ligand-1 (PD-L1) has greatly improved the survival of many cancer patients, especially with metastatic melanoma (82). Due to the inhibition of immune checkpoints, chronic inflammatory, and autoimmune diseases are among the most common adverse events of checkpoint inhibitor treatment in cancer (83). This also includes the induction of BP under checkpoint inhibitor treatment. So far, at least 22 cases of BP have been reported under checkpoint inhibitor treatment $(84,85)$. While this most likely does not greatly add to the rising incidence of BP, the induction of autoimmunity toward BP180 may be a useful indicator to predict checkpoint inhibitor treatment 
outcomes (Poster LB1513 at the 2018 International Investigative Dermatology Meeting).

\section{Increasing Awareness of the Atypical Variants of BP}

Joly et al. (9) suggested that the improving awareness of the recently described clinical variants of $\mathrm{BP}$, which were not recognized in the past, maybe another putative factor contributing to the increasing detection of BP. These BP variants that may appear in up to $20 \%$ of patients include the prurigolike type (86), urticaria-like type (87), eczema-like type (88), dyshidrosiform type (89), erosive type (90), and erythema annulare centrifugatum-like type (30). In a recent systematic review of case reports and series that described BP patients lacking frank bullae, 132 patients with atypical non-bullous presentation had been identified. Urticarial plaques $(52.3 \%)$ and papules/nodules (20.5\%) were the most reported clinical features among these patients. Only $9.8 \%$ of patients developed bullae during the reported follow-up, thus leading to a substantial average delay of 22.6 months until a confirmatory diagnosis of BP (91).

Of interest, two previous studies reporting a growing incidence of $\mathrm{BP}$ revealed that a sizable portion of the patients presented with atypical clinical presentation. Joly et al. (9) found that $20.5 \%$ of their $502 \mathrm{BP}$ patients had atypical clinical variants, of which the majority had prurigo-like and eczema-like variants. Kridin and Bergman (17) noted that $8.4 \%$ of their 287 patients had atypical clinical manifestation, with the urticaria-like and prurigo-like variants as the most common clinical picture seen among these patients.

This assumption is further supported by the recent survey conducted in the SSENIOR study (92). Herein the authors evaluated the prevalence of pruritus and pemphigoid in a high-risk population of nursing home residents. Almost half of the nursing home residents (48\%) complained of pruritus. In addition. seven (6\%) of 126 subjects had pemphigoid, of which four had chronic severe pruritus without blistering [non-bullous pemphigoid (91)], and three had known bullous pemphigoid. Hence, populations at risk, especially when pruritus is present, should be screened for the presence of BP using the appropriate measures. This further supports the assumption that the increased awareness has contributed to the increase in BP, but also highlights that it is likely that the incidence of BP will still increase, as approximately $4 \%$ of an at-risk population had undiagnosed BP.

\section{Better Diagnostic Methods}

In 1953, Dr. Lever distinguished BP from pemphigus based on distinct histologic features, which had been not noted before (93). This distinction based on histomorphologic changes was a landmark discovery, allowing differentiating between pemphigus and pemphigoid. Another breakthrough discovery, which contributed to an improved diagnosis of BP, was the discovery of IgG deposits by direct immunofluorescent (IF) microscopy in skin specimen from BP patients (94). By evaluating direct IF microscopy at high magnification, patterns, such as n- or $\mathrm{u}$-serration become visible. This allows distinguishing between different pemphigoid diseases. However, the BP-associated, nserrated pattern, is present in $\mathrm{BP}$ and other pemphigoid diseases (95). Lastly, the presence of circulating anti-basement membrane autoantibodies in BP patient sera by indirect IF microscopy on human salt-split skin as a substrate was described (96). Indeed, in addition to H\&E stained lesional biopsies, direct and indirect IF microscopy are sufficient to diagnose BP if the disease is suspected. However, these techniques are mostly provided by tertiary centers. To overcome this limitation, methods allowing screening for BP (and other autoimmune skin blistering diseases) have been developed in the past. First, autoantibodies against BP180 and BP230 can be detected by specific ELISA systems (97-99). In addition, paper-based ELISA systems have also been described, but are, not commercially available so far (100).

Second, if substrates for IF microscopy or ELISA are not available, biochips spotted with primate salt-split skin, recombinant BP180 and BP230 expressing cells can be purchased and used for indirect IF microscopy for the detection of circulating autoantibodies directed against BP180 or BP230 (101). This may be even automated, for high-throughput analysis $(102,103)$.

Taken together, direct IF microscopy of a perilesinal skin biopsy for the detection of tissue bound IgG/A and/or C3, and indirect IF microscopy on human salt-split skin for the detection of circulating anti-basement membrane autoantibodies are the minimal diagnostic criteria for BP. If these techniques are not available, specific ELISA systems and/or biochips may be used for BP diagnosis. Hence, a broad spectrum of diagnostic tests has become available, and thus certainly contributed to the increased incidence of BP.

\section{CONCLUSION}

While $\mathrm{BP}$ is still a rare disease, its incidence rises exponentially in the elderly and is associated with remarkable burden. The growing incidence of BP warrants an expanded awareness of the disease, especially on its atypical non-bullous presentations. Alongside practicing dermatologists, other physicians caring for the elderly patients, including general practitioners and geriatricians, should be attentive of the increasing incidence of $\mathrm{BP}$ and to refer patients with a suggestive clinical picture to experienced centers. Caution and careful evaluation should be exercised with regard to the use of DPP4i, particularly in highrisk patients like those with disabling neurological conditions.

\section{AUTHOR CONTRIBUTIONS}

All authors listed have made a substantial, direct and intellectual contribution to the work, and approved it for publication.

\section{ACKNOWLEDGMENTS}

The study was supported by the Excellence Cluster Inflammation at Interfaces (EXC 306/2), and the Clinical Research Unit Pemphigoid Diseases (KFO 303/1) all from the Deutsche Forschungsgemeinschaft. 


\section{REFERENCES}

1. Hammers CM, Stanley JR. Mechanisms of disease: pemphigus and bullous pemphigoid. Annu Rev Pathol Mech Dis. (2016) 11:175-97. doi: 10.1146/annurev-pathol-012615-044313

2. Bernard P, Vaillant L, Labeille B, Bedane C, Arbeille B, Denoeux JP, et al. Incidence and distribution of subepidermal autoimmune bullous skin diseases in three French regions. Bullous Diseases French Study Group. Arch Dermatol. (1995) 131:48-52. doi: 10.1001/archderm.1995.01690130050009

3. Marazza G, Pham HC, Schärer L, Pedrazzetti PP, Hunziker T, Trüeb $\mathrm{RM}$, et al. Incidence of bullous pemphigoid and pemphigus in Switzerland: a 2-year prospective study. Br J Dermatol. (2009) 161:861-8. doi: $10.1111 / j .1365-2133.2009 .09300 . x$

4. Jung M, Kippes W, Messer G, Zillikens D, Rzany B. Increased risk of bullous pemphigoid in male and very old patients: a population-based study on incidence. J Am Acad Dermatol. (1999) 41:266-8.

5. Kridin K. Subepidermal autoimmune bullous diseases: overview, epidemiology, and associations. Immunol Res. (2018) 66:6-17. doi: 10.1007/s12026-017-8975-2

6. Baican A, Baican C, Chiriac G, Chiriac MT, Macovei V, Zillikens D, et al. Pemphigus vulgaris is the most common autoimmune bullous disease in Northwestern Romania. Int J Dermatol. (2010) 49:768-74. doi: 10.1111/j.1365-4632.2009.04345.x

7. Nanda A, Dvorak R, Al-Saeed K, Al-Sabah H, Alsaleh QA. Spectrum of autoimmune bullous diseases in Kuwait. Int J Dermatol. (2004) 43:876-81. doi: 10.1111/j.1365-4632.2004.02292.x

8. Bertram F, Bröcker E-B, Zillikens D, Schmidt E. Prospective analysis of the incidence of autoimmune bullous disorders in Lower Franconia, Germany. $J$ Dtsch Dermatol Ges. (2009) 7:434-40. doi: 10.1111/j.1610-0387.2008.06976.x

9. Joly P, Baricault S, Sparsa A, Bernard P, Bédane C, Duvert-Lehembre S, et al. Incidence and mortality of bullous pemphigoid in France. J Invest Dermatol. (2012) 132:1998-2004. doi: 10.1038/jid.2012.35

10. Wever S, Wever S, Roth A, Weidenthaler-Barth B, Hashimoto T, Bröcker $\mathrm{EB}$, et al. Incidence of autoimmune subepidermal blistering dermatoses in a region of central Germany. Arch Dermatol. (1995) 131:957. doi: 10.1001/archderm.1995.01690200097021

11. Gudi VS, White MI, Cruickshank N, Herriot R, Edwards SL, Nimmot F, et al. Annual incidence and mortality of bullous pemphigoid in the Grampian Region of North-east Scotland. Br J Dermatol. (2005) 153:424-7. doi: 10.1111/j.1365-2133.2005.06662.x

12. Langan SM, Smeeth L, Hubbard R, Fleming KM, Smith CJP, West J. Bullous pemphigoid and pemphigus vulgaris - Incidence and mortality in the UK: population based cohort study. BMJ (2008) 337:160-3. doi: 10.1136/bmj.a180

13. Hübner F, Recke A, Zillikens D, Linder R, Schmidt E. Prevalence and age distribution of pemphigus and pemphigoid diseases in Germany. J Invest Dermatol. (2016) 136:2495-8. doi: 10.1016/j.jid.2016.07.013

14. EURORDIS Rare Diseases Europe. What is a rare disease? Rare Dis Eur. (2007) 14-15.

15. Uzun S, Durdu M, Akman A, Gunasti S, Uslular C, Memisoglu HR, et al. Pemphigus in the Mediterranean region of Turkey: a study of 148 cases. Int $J$ Dermatol. (2006) 45:523-8. doi: 10.1111/j.1365-4632.2004.02533.x

16. Bastuji-Garin S, Joly P, Lemordant P, Sparsa A, Bedane C, Delaporte E, et al. Risk factors for bullous pemphigoid in the elderly: a prospective case-control study. J Invest Dermatol. (2011) 131:637-43. doi: 10.1038/jid.2010.301

17. Kridin K, Bergman R. Ethnic variations in the epidemiology of bullous pemphigoid in Israel. Int J Dermatol. (2017) 57:34-9. doi: 10.1111/ijd.13813

18. Liu Y, Li L, Xia Y. BP180 is critical in the autoimmunity of bullous pemphigoid. Front Immunol. (2017) 8:1752. doi: 10.3389/fimmu.2017.01752

19. Ludwig RJ, Vanhoorelbeke K, Leypoldt F, Kaya Z, Bieber K, McLachlan SM, et al. Mechanisms of autoantibody-induced pathology. Front Immunol. (2017) 8:603. doi: 10.3389/fimmu.2017.00603

20. Haeberle S, Wei X, Bieber K, Goletz S, Ludwig RJ, Schmidt E, et al. Regulatory T-cell deficiency leads to pathogenic bullous pemphigoid antigen 230 autoantibody and autoimmune bullous disease. J Allergy Clin Immunol. (2018). doi: 10.1016/j.jaci.2018. 04.006
21. Muramatsu K, Ujiie H, Kobayashi I, Nishie W, Izumi K, Ito T, et al. Regulatory T-cell dysfunction induces autoantibodies to bullous pemphigoid antigens in mice and human subjects. J Allergy Clin Immunol. (2018). doi: 10.1016/j.jaci.2018.03.014. [Epub ahead of print].

22. Goletz S, Zillikens D, Schmidt E. Structural proteins of the dermal-epidermal junction targeted by autoantibodies in pemphigoid diseases. Exp Dermatol. (2017) 26:1154-62. doi: 10.1111/exd.13446

23. Brinks R, Hoyer A, Weber S, Fischer-Betz R, Sander O, Richter JG, et al. Age-specific and sex-specific incidence of systemic lupus erythematosus: an estimate from cross-sectional claims data of 2.3 million people in the German statutory health insurance 2002. Lupus Sci Med. (2016) 3:e000181. doi: 10.1136/lupus-2016-000181

24. Marrie RA, Cohen J, Stuve O, Trojano M, Sørensen PS, Reingold $S$, et al. A systematic review of the incidence and prevalence of comorbidity in multiple sclerosis: Overview. Mult Scler J. (2015) 21:263-281. doi: $10.1177 / 1352458514564491$

25. Mackenzie IS, Morant SV, Bloomfield GA, MacDonald TM, O'Riordan J. Incidence and prevalence of multiple sclerosis in the UK 1990-2010: a descriptive study in the General Practice Research Database. J Neurol Neurosurg Psychiatry (2014) 85:76-84. doi: 10.1136/jnnp-2013-305450

26. Cozzani E, Parodi A, Rebora A, Delmonte S, Barile M, Nigro A, et al. Bullous pemphigoid in Liguria: A 2-year survey. J Eur Acad Dermatology Venereol. (2001) 15:317-9. doi: 10.1046/j.1468-3083.2001.00275.x

27. Serwin AB, Bokiniec E, Piascik M, Masny D, Chodynicka B. Epidemiological and clinical analysis of pemphigoid patients in northeastern Poland in 2000-2005. Med Sci Monit. (2007) 13:CR360-4.

28. Zillikens D, Wever S, Roth A, Weidenthaler-Barth B, Hashimoto T, Bröcker EB. Incidence of autoimmune subepidermal blistering dermatoses in a region of central Germany. Arch Dermatol. (1995) 131:957-8.

29. Jung M, Kippes W, Messer G, Zillikens D, Rzany B. Increased risk of bullous pemphigoid in male and very old patients: a populationbased study on incidence. J Am Acad Dermatol. (1999) 41:266-8. doi: 10.1016/S0190-9622(99)70061-7

30. Grattan CE. Evidence of an association between bullous pemphigoid and psoriasis. Br J Dermatol. (1985) 113:281-3.

31. World Health Organization. Global Health Observatory (GHO): Data Repository. GHO (2018) Available online at: http://apps.who.int/gho/data/ node.home

32. Eurostat. Mortality and life expectancy statistics. Mortal Life Expect Stat. (2016) 2015-2018.

33. World Bank. Life expectancy at birth, total (years). World Dev Indic. (2015).

34. Pietkiewicz P, Gornowicz-Porowska J, Bowszyc-Dmochowska M, Bartkiewicz P, Dmochowski M. Bullous pemphigoid and neurodegenerative diseases: a study in a setting of a Central European university dermatology department. Aging Clin Exp Res. (2016) 28:659-63. doi: 10.1007/s40520-015-0459-4

35. Chen YJ, Wu CY, Lin MW, Chen TJ, Liao KK, Chen YC, et al. Comorbidity profiles among patients with bullous pemphigoid: a nationwide population-based study. Br J Dermatol. (2011) 165:593-9. doi: 10.1111/j.1365-2133.2011.10386.x

36. Gambichler T, Segert H, Hoxtermann S, Schmitz L, Altmeyer P, Teegen B. Neurological disorders in patients with bullous pemphigoid: clinical and experimental investigations. J Eur Acad Dermatol Venereol. (2015) 29:175862. doi: $10.1111 /$ jdv. 12995

37. Jedlickova H, Hlubinka M, Pavlik T, Semradova V, Budinska E, Vlasin Z. Bullous pemphigoid and internal diseases - a case-control study. Eur J Dermatol. (2010) 20:96-101. doi: 10.1684/ejd.2010.0805

38. Langan SM, Groves RW, West J. The relationship between neurological disease and bullous pemphigoid: a population-based case-control study. $J$ Invest Dermatol. (2011) 131:631-6. doi: 10.1038/jid.2010.357

39. Cordel N, Chosidow O, Hellot MF, Delaporte E, Lok C, Vaillant L, et al. Neurological disorders in patients with bullous pemphigoid. Dermatology (2007) 215:187-91. doi: 10.1159/000106574

40. Taghipour K, Chi CC, Vincent A, Groves RW, Venning V, Wojnarowska F. The association of bullous pemphigoid with cerebrovascular disease and dementia. Arch Dermatol. (2010) 146:1251-4. doi: 10.1001/archdermatol.2010.322 
41. Cai SCS, Allen JC, Lim YL, Chua SH, Tan SH, Tang MBY. Mortality of bullous pemphigoid in Singapore: risk factors and causes of death in 359 patients seen at the National Skin Centre. Br J Dermatol. (2014) 170:1319-26. doi: 10.1111/bjd.12806

42. Rzany B, Partscht K, Jung M, Kippes W, Mecking D, Baima B, et al. Risk factors for lethal outcome in patients with bullous pemphigoid: low serum albumin level, high dosage of glucocorticosteroids, and old age. Arch Dermatol. (2002) 138:903-8.

43. Chevalier V, Barbe C, Reguiai Z, Plée J, Grange F, Bernard P. Impact pronostique des maladies neurologiques au cours de la pemphigoïde bulleuse: étude rétrospective de 178 cas. Ann Dermatol Venereol. (2016) 143:179-86. doi: 10.1016/j.annder.2015.12.016

44. GBD 2015 Neurological Disorders Collaborator Group G 2015 NDC. Global, regional, and national burden of neurological disorders during 1990-2015: a systematic analysis for the Global Burden of Disease Study 2015. Lancet Neurol. (2017) 16:877-97. doi: 10.1016/S1474-4422(17)30299-5

45. Mathillas J, Lövheim $\mathrm{H}$, Gustafson $\mathrm{Y}$. Increasing prevalence of dementia among very old people. Age Ageing (2011) 40:243-9. doi: 10.1093/ageing/afq173

46. Feigin VL, Lawes CM, Bennett DA, Barker-Collo SL, Parag V. Worldwide stroke incidence and early case fatality reported in 56 populationbased studies: a systematic review. Lancet Neurol. (2009) 8:355-69. doi: 10.1016/S1474-4422(09)70025-0

47. Sander JW, Keezer MR. Epilepsy: Trends in new-onset epilepsy The importance of comorbidities. Nat Rev Neurol. (2016) 12:254-6. doi: 10.1038/nrneurol.2016.32

48. Dahlrot RH, Poulsen FR, Nguyen NNTT, Kristensen BW, Hansen $\mathrm{S}$, Holm NV. Trends in tumors in the central nervous system in elderly in Denmark, 2008-2012. Acta Oncol. (2016) 55:91-7. doi: 10.3109/0284186X.2015.1115123

49. Grytten N, Torkildsen $\varnothing$, Myhr KM. Time trends in the incidence and prevalence of multiple sclerosis in Norway during eight decades. Acta Neurol Scand. (2015) 132:29-36. doi: 10.1111/ane.12428

50. Alla S, Pearson J, Debernard L, Miller D, Mason D. The increasing prevalence of multiple sclerosis in New Zealand. Neuroepidemiology (2014) 42:154-60. doi: $10.1159 / 000358174$

51. Amber KT, Zikry J, Hertl M. A multi-hit hypothesis of bullous pemphigoid and associated neurological disease: is HLA-DQB1*03:01, a potential link between immune privileged antigen exposure and epitope spreading? HLA (2017) 89:127-34. doi: 10.1111/tan.12960

52. Li L, Chen J, Wang B, Yao Y, Zuo Y. Sera from patients with bullous pemphigoid (BP) associated with neurological diseases recognized BP antigen 1 in the skin and brain. Br J Dermatol. (2009) 160:1343-5. doi: 10.1111/j.1365-2133.2009.09122.x

53. Brown A, Bernier G, Mathieu M, Rossant J, Kothary R. The mouse dystonia musculorum gene is a neural isoform of bullous pemphigoid antigen 1. Nat Genet. (1995) 10:301-6. doi: 10.1038/ng0795-301

54. Seppänen A, Autio-Harmainen H, Alafuzoff I, Särkioja T, Veijola J, Hurskainen T, et al. Collagen XVII is expressed in human CNS neurons. Matrix Biol. (2006) 25:185-8. doi: 10.1016/j.matbio.2005. 11.004

55. Claudepierre T, Manglapus MK, Marengi N, Radner S, Champliaud MF, Tasanen K, et al. Collagen XVII and BP AG1 expression in the retina: Evidence for an anchoring complex in the central nervous system. J Comp Neurol. (2005) 487:190-203. doi: 10.1002/cne.20549

56. Guo L, Degenstein L, Dowling J, Yu QC, Wollmann R, Perman B, Fuchs E. Gene targeting of BPAG1: abnormalities in mechanical strength and cell migration in stratified epithelia and neurologic degeneration. Cell (1995) 81:233-43. doi: 10.1016/0092-8674(95)90333-X

57. Benzaquen M, Borradori L, Berbis P, Cazzaniga S, Valero R, Richard MA, et al. Dipeptidyl peptidase IV inhibitors, a risk factor for bullous pemphigoid: retrospective multicenter case-control study from France and Switzerland. $J$ Am Acad Dermatol. (2017) 78:1090-6 doi: 10.1016/j.jaad.2017.12.038

58. Varpuluoma O, Försti AK, Jokelainen J, Turpeinen M, Timonen M, Huilaja L, et al. Vildagliptin significantly increases the risk of bullous pemphigoid: a Finnish nationwide registry study. J Invest Dermatol. (2018) 138:1659-61. doi: 10.1016/j.jid.2018.01.027
59. Keseroglu HO, Taş-Aygar G, Gönül M, Gököz O, Ersoy-Evans S. A case of bullous pemphigoid induced by vildagliptin. Cutan Ocul Toxicol. (2017) 36:201-2. doi: 10.1080/15569527.2016.1211670

60. Haber R, Fayad AM, Stephan F, Obeid G, Tomb R. Bullous pemphigoid associated with linagliptin treatment. JAMA Dermatol. (2016) 152:224-6. doi: 10.1001/jamadermatol.2015.2939

61. Mendonça FMI, Martín-Gutierrez FJ, Ríos-Martín JJ, Camacho-Martinez F. Three cases of bullous pemphigoid associated with dipeptidyl peptidase4 inhibitors - one due to Linagliptin. Dermatology (2016) 232:249-53. doi: $10.1159 / 000443330$

62. Skandalis K, Spirova M, Gaitanis G, Tsartsarakis A, Bassukas ID. Drug-induced bullous pemphigoid in diabetes mellitus patients receiving dipeptidyl peptidase-IV inhibitors plus metformin. J Eur Acad Dermatology Venereol. (2012) 26:249-53. doi: 10.1111/j.1468-3083.2011.04062.x

63. Béné J, Jacobsoone A, Coupe P, Auffret M, Babai S, Hillaire-Buys D, et al. Bullous pemphigoid induced by vildagliptin: a report of three cases. Fundam Clin Pharmacol. (2015) 29:112-4. doi: 10.1111/fcp.12083

64. Pasmatzi E, Monastirli A, Habeos J, Georgiou S, Tsambaos D. Dipeptidyl peptidase- 4 inhibitors cause bullous pemphigoid in diabetic patients: report of two cases. Diabetes Care (2011) 34:e133. doi: 10.2337/dc11-0804

65. Aouidad I, Fite C, Marinho E, Deschamps L, Crickx B, Descamps V. A case report of bullous pemphigoid induced by dipeptidyl peptidase- 4 inhibitors. JAMA Dermatol. (2013) 149:243-5. doi: 10.1001/jamadermatol.2013.1073

66. Attaway A, Mersfelder TL, Vaishnav S, Baker JK. Bullous pemphigoid associated with dipeptidyl peptidase IV inhibitors. A case report and review of literature. J Dermatol Case Rep. (2014) 8:24-8. doi: 10.3315/jdcr.2014.1166

67. Béné J, Moulis G, Bennani I, Auffret M, Coupe P, Babai S, et al. Bullous pemphigoid and dipeptidyl peptidase IV inhibitors: a case-noncase study in the French Pharmacovigilance Database. Br J Dermatol. (2016) 175:296-301. doi: 10.1111/bjd.14601

68. García M, Aranburu MA, Palacios-Zabalza I, Lertxundi U, Aguirre C. Dipeptidyl peptidase-IV inhibitors induced bullous pemphigoid: a case report and analysis of cases reported in the European pharmacovigilance database. J Clin Pharm Ther. (2016) 41:368-70. doi: 10.1111/jcpt.12397

69. Gravani A, Gaitanis G, Tsironi T, Tigas S, Bassukas ID. Changing prevalence of diabetes mellitus in bullous pemphigoid: It is the dipeptidyl peptidase-4 inhibitors. J Eur Acad Dermatology Venereol. (2018). doi: 10.1111/jdv.14957. [Epub ahead of print].

70. Gaudin O, Seta V, Alexandre M, Bohelay G, Aucouturier F, MignotGrootenboer S, et al. Gliptin accountability in mucous membrane pemphigoid induction in 24 out of 313 patients. Front Immunol. (2018) 9:1030. doi: 10.3389/fimmu.2018.01030

71. Izumi K, Nishie W, Mai Y, Wada M, Natsuga K, Ujiie $H$, et al. Autoantibody profile differentiates between inflammatory and noninflammatory bullous pemphigoid. J Invest Dermatol. (2016) 136:2201-10. doi: 10.1016/j.jid.2016.06.622

72. Chijiwa C, Takeoka S, Kamata M, Tateishi M, Fukaya S, Hayashi K, et al. Decrease in eosinophils infiltrating into the skin of patients with dipeptidyl peptidase-4 inhibitor-related bullous pemphigoid. J Dermatol. (2018) 45:596-99. doi: 10.1111/1346-8138.14245

73. García-Díez I, Ivars-Lleó M, López-Aventín D, Ishii N, Hashimoto T, Iranzo $\mathrm{P}$, et al. Bullous pemphigoid induced by dipeptidyl peptidase- 4 inhibitors. Eight cases with clinical and immunological characterization. Int J Dermatol. (2018) 57:810-6. doi: 10.1111/ijd.14005

74. Kawaguchi Y, Shimauchi R, Nishibori N, Kawashima K, Oshitani S, Fujiya A, et al. Dipeptidyl peptidase-4 inhibitors-associated bullous pemphigoid: a retrospective study of 168 pemphigoid and 9,304 diabetes mellitus cases. $J$ Diabetes Investig. (2018). doi: 10.1111/jdi.12877. [Epub ahead of print].

75. Ujiie H, Muramatsu K, Mushiroda T, Ozeki T, Miyoshi H, Iwata $H$, et al. HLA-DQB1*03:01 as a biomarker for genetic susceptibility to bullous pemphigoid induced by DPP-4 inhibitors. J Invest Dermatol. (2018) 138:1201-4. doi: 10.1016/j.jid.2017.11.023

76. Gonzalez-Gronow M, Kaczowka S, Gawdi G, Pizzo S V. Dipeptidyl peptidase IV (DPP IV/CD26) is a cell-surface plasminogen receptor. Front Biosci. (2008) 13:1610-8. doi: 10.2741/2785

77. Hofmann SC, Voith U, Schönau V, Sorokin L, Bruckner-Tuderman L, Franzke CW. Plasmin plays a role in the in vitro generation of the linear 
IgA dermatosis antigen LADB97. J Invest Dermatol. (2009) 129:1730-9. doi: 10.1038/jid.2008.424

78. Forssmann U, Stoetzer C, Stephan M, Kruschinski C, Skripuletz T, Schade J, et al. Inhibition of CD26/dipeptidyl peptidase IV Enhances CCL11/eotaxinmediated recruitment of eosinophils in vivo. J Immunol. (2008) 181:1120-7. doi: 10.4049/jimmunol.181.2.1120

79. Bastuji-Garin S, Joly P, Picard-Dahan C, Bernard P, Vaillant L, Pauwels C, et al. Drugs associated with bullous pemphigoid. A case-control study. Arch Dermatol. (1996) 132:272-6. doi: 10.1001/archderm.132.3.272

80. Maust DT, Gerlach LB, Gibson A, Kales HC, Blow FC, Olfson M. Trends in central nervous system-active polypharmacy among older adults seen in outpatient care in the United States. JAMA Intern Med. (2017) 177:583-5. doi: 10.1001/jamainternmed.2016.9225

81. Kantor ED, Rehm CD, Haas JS, Chan AT, Giovannucci EL. Trends in prescription drug use among adults in the United States from 1999-2012. JAMA (2015) 314:1818. doi: 10.1001/jama.2015.13766

82. Robert C, Schachter J, Long GV, Arance A, Grob JJ, Mortier L, et al. Pembrolizumab versus Ipilimumab in Advanced Melanoma. $N$ Engl J Med. (2015) 372:2521-32. doi: 10.1056/NEJMoa1503093

83. Day D, Hansen AR. Immune-related adverse events associated with immune checkpoint inhibitors. Biodrugs (2016) 30:571-84. doi: 10.1007/s40259-016-0204-3

84. Lopez AT, Khanna T, Antonov N, Audrey-Bayan C, Geskin L. A review of bullous pemphigoid associated with PD-1 and PD-L1 inhibitors. Int $J$ Dermatol. (2018) 57:664-9. doi: 10.1111/ijd.13984

85. Amber KT, Valdebran M, Lu Y, De Feraudy S, Linden KG. Localized pretibial bullous pemphigoid arising in a patient on pembrolizumab for metastatic melanoma. J Dtsch Dermatol Ges. (2018) 16:196-8. doi: 10.1111/ddg.13411

86. Schmidt E, Sitaru C, Schubert B, Wesselmann U, Kromminga A, Bröcker EB, et al. Subacute prurigo variant of bullous pemphigoid: autoantibodies show the same specificity compared with classic bullous pemphigoid. J Am Acad Dermatol. (2002) 47:133-6.

87. Lamb PM, Abell E, Tharp M, Frye R, Deng J-S. Prodromal bullous pemphigoid. Int $J$ Dermatol. (2006) 45:209-14. doi: 10.1111/j.1365-4632.2004.02457.x

88. Strohal R, Rappersberger K, Pehamberger H, Wolff K. Nonbullous pemphigoid: prodrome of bullous pemphigoid or a distinct pemphigoid variant? J Am Acad Dermatol. (1993) 29:293-9.

89. Levine N, Freilich A, Barland P. Localized pemphigoid simulating dyshidrosiform dermatitis. Arch Dermatol. (1979) 115:320-1. doi: 10.1001/archderm.1979.04010030028010

90. Cordel N, Courville P, Martel P, Musette P, Joly P. Extensive erosive bullous pemphigoid: an atypical and serious clinical variant [11]. $\mathrm{Br} J$ Dermatol. (2002) 146:537-9. doi: 10.1046/j.1365-2133.2002.465611.x

91. Lamberts A, Meijer JM, Jonkman MF. Nonbullous pemphigoid: a systematic review. J Am Acad Dermatol. (2018) 78:989-95.e2. doi: 10.1016/j.jaad.2017.10.035

92. Meijer JM, Lamberts A, Luijendijk D, Diercks GFH, Pas HH, Zuidema SU, et al. 280 Prevalence of pruritus and pemphigoid in nursing home residents (SSENIOR): a cross-sectional study of an unmet need. J Invest Dermatol. (2018) 138:S48. doi: 10.1016/J.JID.2018.03.286
93. Lever WF. Pemphigus. Medicine (1953) 32:1-123.

94. Jordon RE, Beutner EH, Witebsky E, Blumental G, Hale WL, Lever WF. Basement zone antibodies in bullous pemphigoid. J Am Med Assoc. (1967) 200:751-6. doi: 10.1001/jama.1967.03120220053008

95. Vodegel RM, Jonkman MF, Pas HH, De Jong MCJM. U-serrated immunodeposition pattern differentiates type VII collagen targeting bullous diseases from other subepidermal bullous autoimmune diseases. $\mathrm{Br} J$ Dermatol. (2004) 151:112-8. doi: 10.1111/j.1365-2133.2004.06006.x

96. Kumar V, Beutner EH. Direct immunofluorescence studies of sodium chloride-separated skin in the differential diagnosis of bullous pemphigoid and epidermolysis bullosa acquisita. J Am Acad Dermatol. (1990) 22:664-70. doi: 10.1016/0190-9622(90)70094-X

97. Sitaru C, Dähnrich C, Probst C, Komorowski L, Blöcker I, Schmidt E, et al. Enzyme-linked immunosorbent assay using multimers of the 16th non-collagenous domain of the BP180 antigen for sensitive and specific detection of pemphigoid autoantibodies. Exp Dermatol. (2007) 16:770-7. doi: $10.1111 / j .1600-0625.2007 .00592 . x$

98. Yoshida M, Hamada T, Amagai M, Hashimoto K, Uehara R, Yamaguchi $\mathrm{K}$, et al. Enzyme-linked immunosorbent assay using bacterial recombinant proteins of human BP230 as a diagnostic tool for bullous pemphigoid. $J$ Dermatol Sci. (2006) 41:21-30. doi: 10.1016/j.jdermsci.2005.11.002

99. Blöcker IM, Dähnrich C, Probst C, Komorowski L, Saschenbrecker S, Schlumberger W, et al. Epitope mapping of BP230 leading to a novel enzymelinked immunosorbent assay for autoantibodies in bullous pemphigoid. $\mathrm{Br} \mathrm{J}$ Dermatol. (2012) 166:964-70. doi: 10.1111/j.1365-2133.2012.10820.x

100. Hsu CK, Huang HY, Chen WR, Nishie W, Ujiie H, Natsuga K, et al. Paper-based ELISA for the detection of autoimmune antibodies in body fluid-the case of bullous pemphigoid. Anal Chem. (2014) 86:4605-10. doi: $10.1021 /$ ac500835k

101. van Beek N, Rentzsch K, Probst C, Komorowski L, Kasperkiewicz M, Fechner K, et al. Serological diagnosis of autoimmune bullous skin diseases: Prospective comparison of the BIOCHIP mosaic-based indirect immunofluorescence technique with the conventional multi-step single test strategy. Orphanet J Rare Dis. (2012) 7:49. doi: 10.1186/1750-1172-7-49

102. Lemcke S, Sokolowski S, Rieckhoff N, Buschtez M, Kaffka C, Winter-Keil A, et al. Automated direct immunofluorescence analyses of skin biopsies. $J$ Cutan Pathol. (2016) 43:227-35. doi: 10.1111/cup.12637

103. Kridin K, Bergman R. Dipeptidyl-peptidase IV inhibitors-associated bullous pemphigoid: estimating the risk of the new agents and characterizing the patients. JAMA Dermatol. (2018). doi: 10.1001/jamadermatol.2018.2352

Conflict of Interest Statement: The authors declare that the research was conducted in the absence of any commercial or financial relationships that could be construed as a potential conflict of interest.

Copyright $\odot 2018$ Kridin and Ludwig. This is an open-access article distributed under the terms of the Creative Commons Attribution License (CC BY). The use, distribution or reproduction in other forums is permitted, provided the original author(s) and the copyright owner(s) are credited and that the original publication in this journal is cited, in accordance with accepted academic practice. No use, distribution or reproduction is permitted which does not comply with these terms. 